\title{
MORT CREEK SITE COMPLEX, CURTIS COAST: SITE REPORT
}

\author{
MELISSA CARTER, IAN LILLEY, SEAN ULM AND DEBORAH BRIAN \\ Aboriginal and Torres Strait Islander Studies Unit, University of Queensland, \\ Brisbane, Queensland, 4072, Australia
}

\begin{abstract}
This paper reports the results of excavations conducted at the Mort Creek Site Complex, located in the Rodds Peninsula Section of Eurimbula National Park on the southern Curtis Coast, Central Queensland. Cultural and natural marine shell deposits were excavated and analysed as part of an investigation of natural and cultural site formation processes in the area. Analyses (including foraminifera studies) demonstrate a complex site formation history, with interfingering of cultural and natural shell deposits (cheniers) in some areas of the site. Radiocarbon dating indicates that Aboriginal occupation of the site was initiated before 2,000 cal BP, overlapping with dates obtained for natural chenier deposits.
\end{abstract}

\section{Introduction}

This paper details the results of excavations undertaken during January 1995 at the Mort Creek Site Complex on the Central Queensland coast. In previous publications the site has been called 'Rodds Peninsula' (Lilley et al. 1996) and the 'Rodds Peninsula Site Complex' (Carter 1997). The site is registered as Queensland State File Number KE:A41 and Queensland Museum Site Number S866.

The excavations had two primary aims. The first was to distinguish areas of non-cultural deposit, such as cheniers, from shell middens. The second aim was to determine whether surface indications gave an accurate picture of the nature and distribution of shell deposits in the study area. In the laboratory, a further research aim of these excavations was to test the applicability of foraminifera analysis, a microanalytical technique with the potential to help distinguish cultural and natural marine shell deposits.

\section{Site Location and Description}

The Mort Creek Site Complex is located on the west bank of Mort Creek, on the west coast of Rodds Peninsula in the Rodds Peninsula Section of Eurimbula National Park. The site is located $30 \mathrm{~km}$ northwest of Round Hill Head and 36km northnortheast of the town of Miriam Vale (Latitude: $24^{\circ} 00^{\prime} 45^{\prime \prime}$; Longitude: $151^{\circ} 37^{\prime} 45^{\prime \prime}$; Easting: 360630 ; Northing: 7343809). The deposits front the shallow, open waters of Rodds Harbour to the south and west and a large area of tidal mangroves and mudflats to the east (Figures 1-2).

Three excavations, designated 'The Granites', 'White Patch' and 'A7', were conducted in an area characterised by a complex of beach ridges, cheniers, shell middens and tidal inlets, referred to collectively as the Mort Creek Site Complex. The extent of shell deposits is considerable, covering an area of approximately 6 ha (Lilley et al. 1999). The Granites excavation was located on a low ridge composed of approximately $1 \mathrm{~m}$ of sand overlying microgranite bedrock. The White Patch deposit was located to the south of a small inlet in an area of sandy beach ridges and cheniers. The excavation A7 was located to the west of a branch of the inlet in an area of sandy ridges with virtually no surface shell.

\section{Excavation Aims and Methods}

The shell deposits of the Mort Creek Site Complex were initially reported by Burke (1993) as CC-067 (KE:A49) and CC-068 (KE:A50) during a heritage management study of the Curtis Coast. She described the area as an Aboriginal site of 'high significance' (Burke 1993:Table 17). On the Queensland Environmental Protection Agency Site Index Card completed for site CC-067 (KE:A49), Burke notes that "this shell midden appears to be interspersed with a natural beach ridge. It was quite difficult to determine if the midden was real or natural, it seems to me that it is probably a mixture of both."

After exploratory field inspection in late 1994, a team from the University of Queensland and the Gurang Land Council Aboriginal Corporation conducted preliminary archaeological surveys and excavation on Rodds Peninsula between 22-28 January 1995 to assess the archaeological research potential of the marine shell deposits in the area.

Detailed surface survey of the area confirmed Burke's observations that while they may feature a sparse surface veneer of humanly-deposited shell, the shell ridges were clearly natural in origin (Lilley et al. 1999). Further intensive field survey located areas exhibiting sparse scatterings of shell and others with virtually no surface shell. In an attempt to distinguish middens from areas of non-cultural deposit such as cheniers, and to determine whether the surface indications gave a true picture of the nature and distribution of shell deposits in the area, the entire region was investigated more thoroughly with a program of subsurface testing (Lilley et al. 1997). 


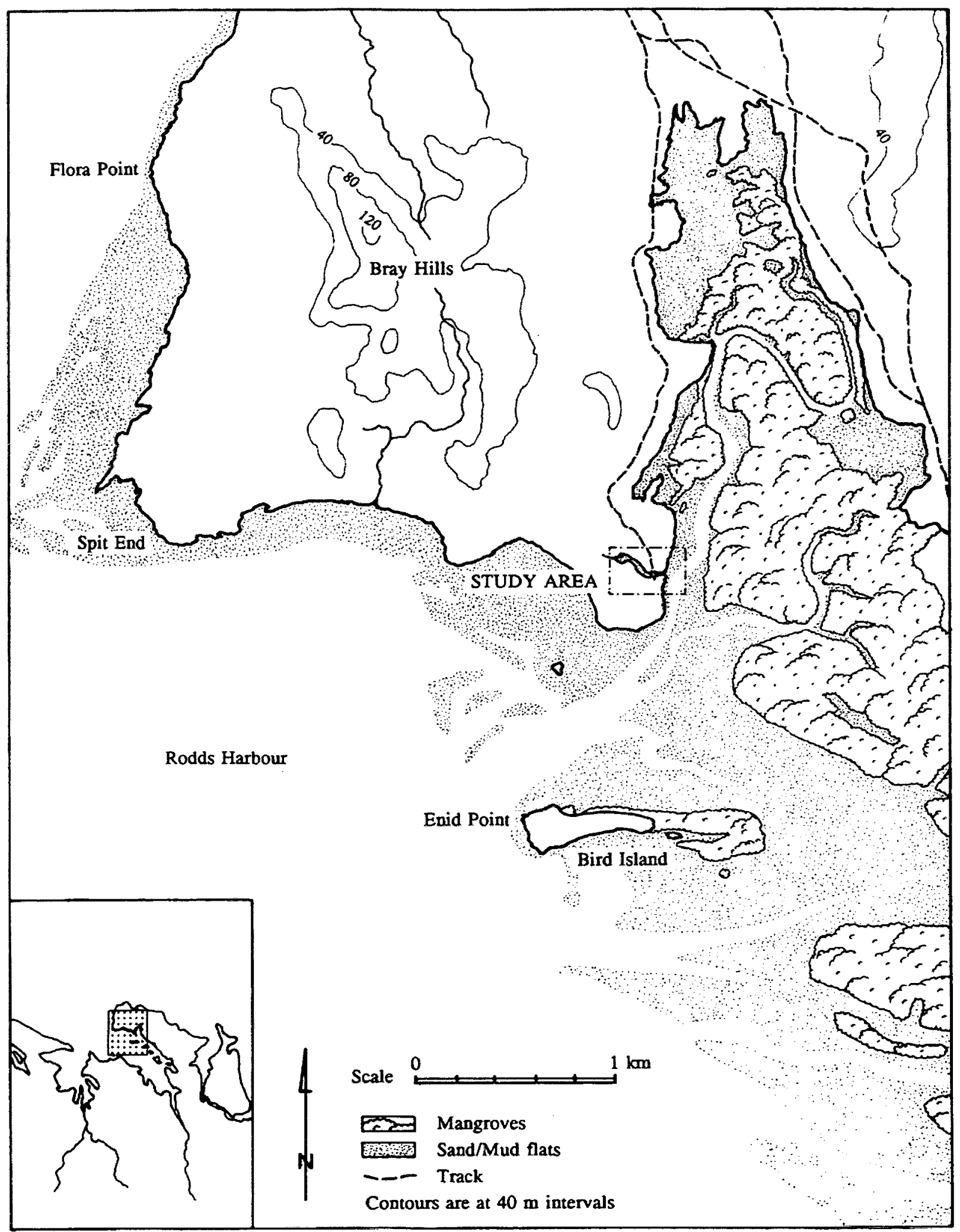

Figure 1. Rodds Peninsula, showing the location of the Mort Creek Site Complex study area. 


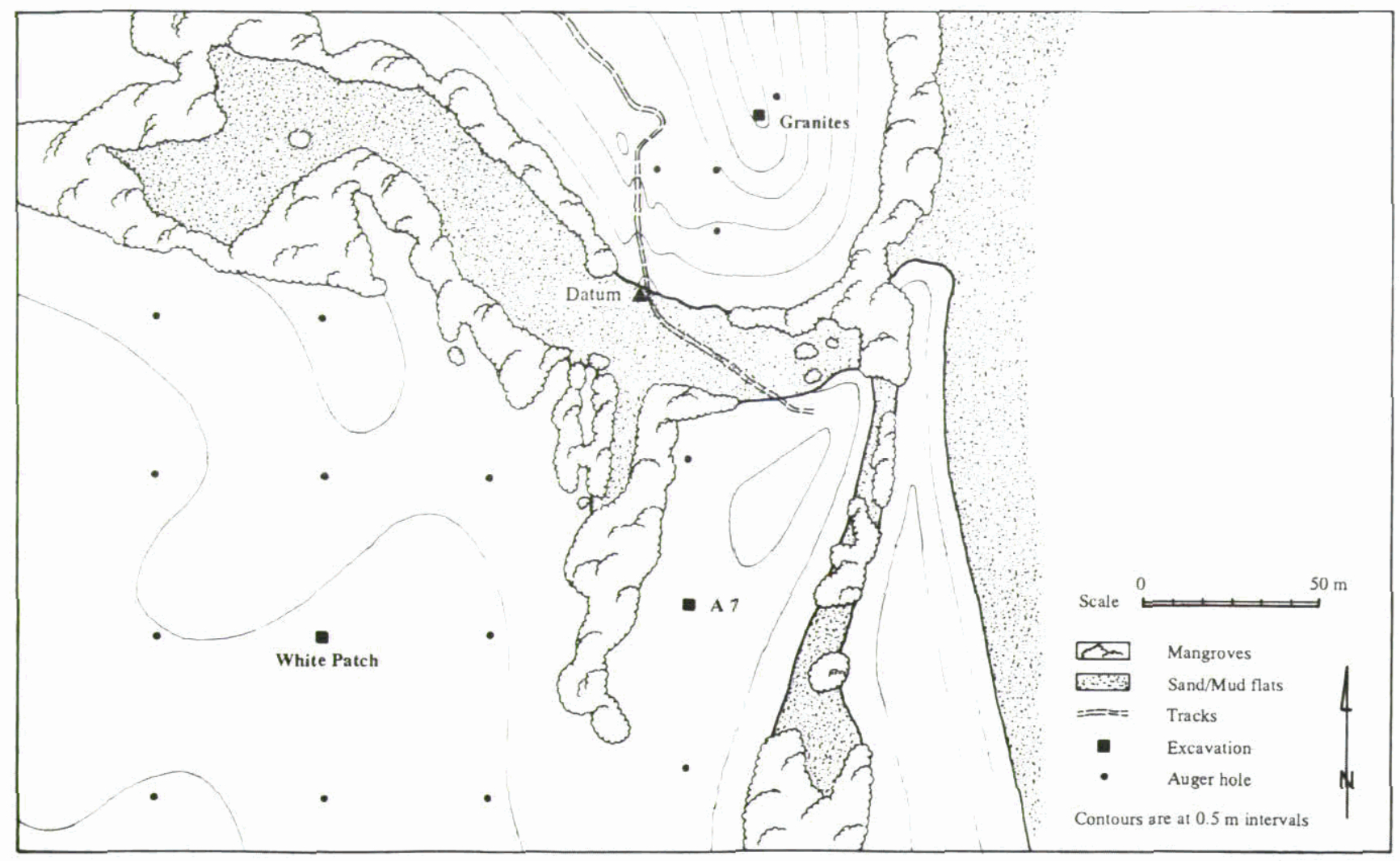

Figure 2. Mort Creek Site Complex, showing locations of subsurface testing.

Initially the local topography was mapped with an autoset level and stadia rod. To gain broad information on the extent and depth of the shell deposits, a grid of $38 \times 75 \mathrm{~mm}$ auger holes was drilled across the study region at $50 \mathrm{~m}$ intervals. The results demonstrated that there were substantial subsurface shell deposits over the entire area, including those parts where surface shell was largely absent. To assess the stratigraphy more accurately and to obtain control samples of the deposits, three $50 \mathrm{~cm} \times 50 \mathrm{~cm}$ test pits were excavated in areas with different surface expressions of shell.

The excavations were located to obtain a representative sample of the range of shell deposits observed over the entire study area. The Granites excavation was situated in a locale which was hypothesised to contain shell midden deposit. The excavation known as White Patch was conducted in a place hypothesised to comprise natural beach ridges and chenier deposits. Displaying no surface shell material, the third site, known as A7, was excavated to determine the cultural status of the dense subsurface shell deposits which had been revealed by augering.

The three test pits were excavated by trowel in arbitrary $2-5 \mathrm{~cm}$ excavation units within stratigraphic units. Elevations were recorded at the beginning and end of each excavation unit, using a local datum and string line and level. Major finds were plotted in situ in three dimensions and bagged separately. Most excavated sediment was dry-sieved on site through $6 \mathrm{~mm}$ and $3 \mathrm{~mm}$ mesh, and sieve residues and samples of fine material which passed through the screens were retained for laboratory analysis. The basal excavation units of A7 were wet-sieved in seawater from the adjacent estuary as the moisture content of the excavated sand prevented effective dry-sieving. Bulk sediment samples, however, were taken prior to wet-sieving. Control samples for foraminifera analysis were collected from shelly intertidal deposits on the west bank of Mort Creek and from a long chenier fronting Rodds Harbour to the south.

\section{Stratigraphy \\ The Granites}

The Granites excavation was located on a low ridge bordered by estuaries to the east and south (Figure 2). Excavation at The Granites revealed three stratigraphic units (SUs) overlying bedrock (Figure 5 ). The uppermost $\mathrm{SU}$ consisted of a layer of darkcoloured sand some $20-25 \mathrm{~cm}$ deep and containing large mud ark Anadara trapezia shells, fish bone. charcoal and occasional stone artefacts. The second $\mathrm{SU}$ comprised a layer of lighter-coloured sand of 
similar depth containing some shell. SUIII consisted of densely-packed shell fragments some $25-30 \mathrm{~cm}$ deep. On the basis of conventional criteria used to distinguish middens, namely the presence of larger shells, bone, charcoal and stone artefacts, The Granites excavation was concluded to have exposed a shell midden overlying a chenier deposit resting on microgranite bedrock. More detailed examination of the shell assemblage indicated that there was a veneer of culturally-deposited shell on top of the basal chenier (Carter 1997; Lilley et al. 1996). The natural formation proved to be substantially older than the cultural shells lying directly on its surface (see discussion below).

\section{White Patch}

Located to the south of a small tidal inlet (Figure 2), the White Patch test pit revealed a deposit consisting entirely of densely-packed shell and shell fragments (Figures 3,6). Excavation demonstrated the presence of four natural stratigraphic units (SUs). The uppermost (SUI) consisted of dark-brown organic top soil, densely packed with shell fragments and some large shells including hercules club shell, mud ark and land snail, and ranging from c. $10-20 \mathrm{~cm}$ in depth. SUII exhibited an increase in shell and shell grit, with little soil. Sub-unit SUIIA of this layer was distinct, containing shell and shell grit but characterised by a grey soil matrix. SUIII contained densely-packed shell with many large individuals, in a reddishcoloured sandy matrix. An absence of charcoal, bone and stone artefacts was observed during excavation. Also noted by the excavators were patches of oddsmelling, grey-coloured shell amid the more usual pinky-brown coloured material. This was concluded to be evidence for seawater penetration and mineral precipitation. Based on these characteristics, White Patch was determined to be entirely of natural origin, and classified as chenier deposit.

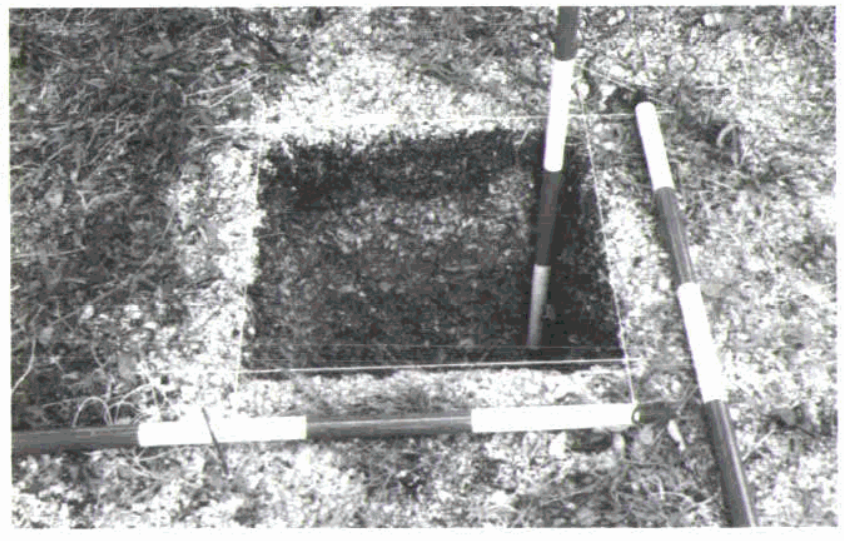

Figure 3. White Patch showing densely-packed chenier deposits (Photograph: I. Lilley).

\section{A7}

A7 is located to the west of a small tidal inlet in an area with virtually no surface shell (Figure 2 ). Auger Hole 7 (from which the name A7 derives) revealed a dense shell layer some $10-15 \mathrm{~cm}$ thick located approximately $20 \mathrm{~cm}$ below ground surface (Figures $4,7)$. The presence of this layer was confirmed by excavation. As augering had indicated, the uppermost stratigraphic unit (SUI) consisted entirely of soil and root matter. SUII consisted of large shells, predominantly mud ark (Anadara trapezia) and commercial oyster (Saccostrea commercialis), in a medium- to dark-brown soil matrix. Smaller shells were also noted. The matrix of this unit was substantially sandier and more yellow in colour than the matrix observed in the stratigraphic unit above. SUIII exhibited a decrease in the number of large shells, with a noticeable increase in fragmented shell and shell grit. The matrix of this unit consisted of an orange-red sand. At this point in the excavation of A7 $(\mathrm{c} .90 \mathrm{~cm})$ the water table was reached, and excavation ceased, as the base of the pit filled with water and the sections threatened to collapse.

Although the A7 excavation looked like a shell midden in that it contained abundant, seemingly sizeselected mud ark, as well as what field observation suggested might be a shell artefact from the base of the dense shell layer (Culbert 1996), classification problems remained. The soil matrix of the deposit appeared different from the dark, organic sediment usually associated with middens (Lilley et al. 1999). The deposit also contained little or no charcoal and no other artefacts, and exhibited a much wider variety of shell species in a greater range of sizes than in The Granites deposit. On the basis of this ambiguity, A7 was seen as a primary candidate for the application of foraminifera analysis to test its utility as an additional aid in distinguishing middens from natural shell deposits (Lilley et al. 1999).

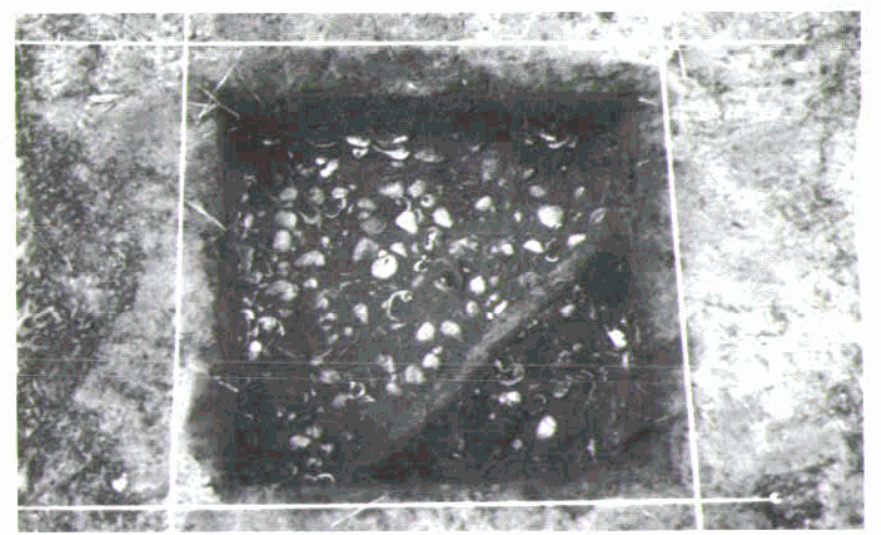

Figure 4. A7 showing dense shell lens dominated by large mud ark (Photograph: S. Ulm). 


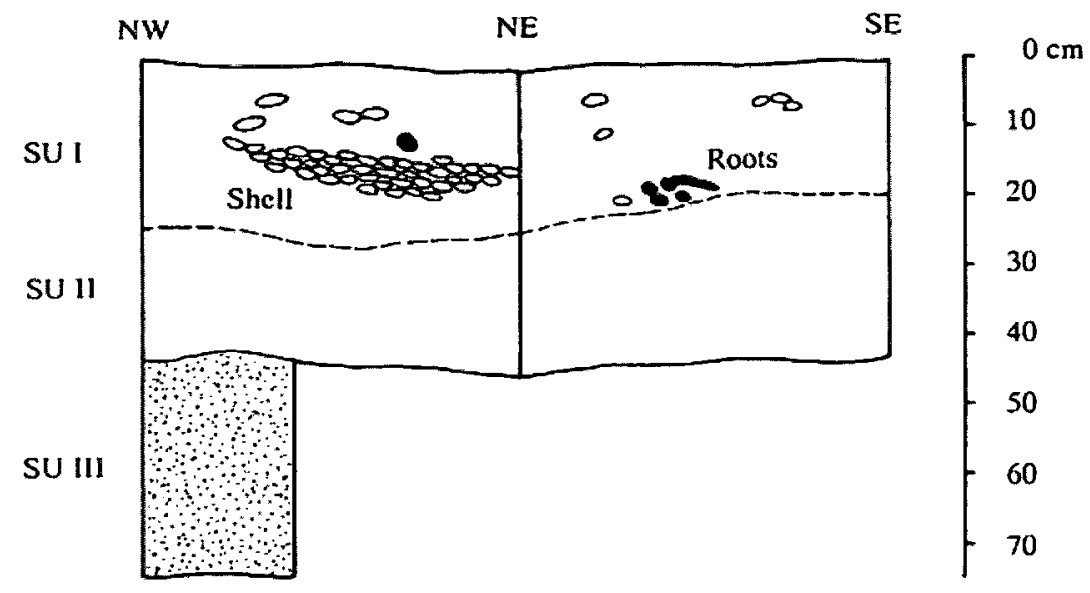

Figure 5. Northern and eastern stratigraphic profiles of The Granites.

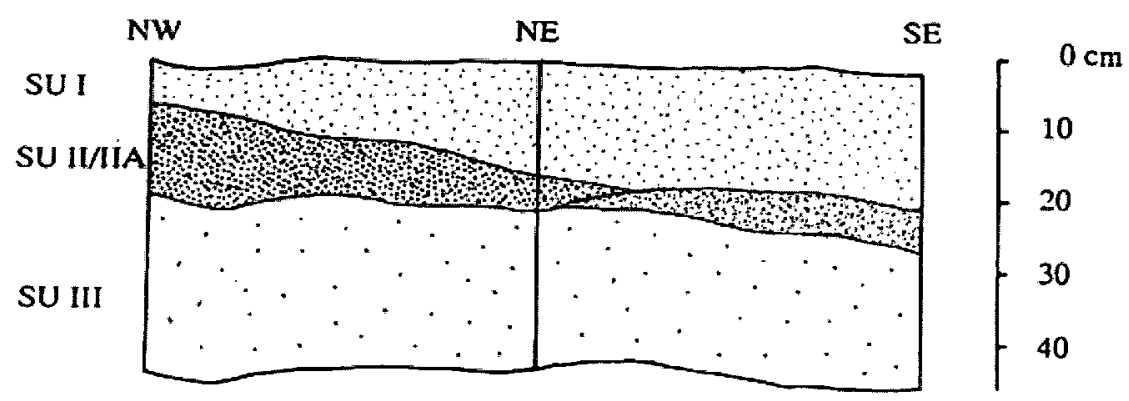

Figure 6. Northern and eastern stratigraphic profiles of White Patch.

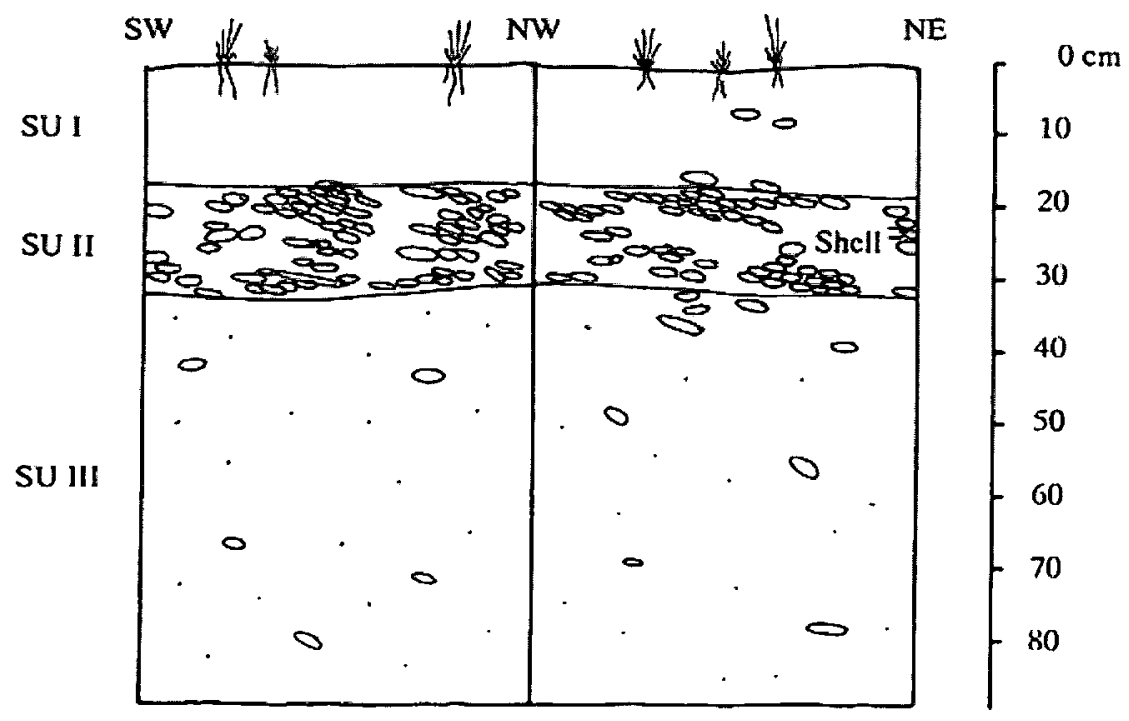

Figure 7. Northern and western stratigraphic profiles of A7. 
Table 1. Radiocarbon dates for the Mort Creek Site Complex.

\begin{tabular}{|c|c|c|c|c|c|c|c|}
\hline Square & XU & $\begin{array}{c}\text { Depth } \\
(\mathbf{c m})\end{array}$ & Lab.No. & Sample & $\begin{array}{c}\text { Weight } \\
(\mathrm{g})\end{array}$ & ${ }^{14}$ C Age & Calibrated Age/s \\
\hline A7 & 4 & $18-20.2$ & Wk-5602 & shell $^{\mathrm{a}}$ & 47.3 & $2880 \pm 50$ & $2755(2692) 2450$ \\
\hline A7 & 6 & $22.6-26.7$ & Wk-3937 & shell $^{\mathrm{a}}$ & 75.2 & $2930 \pm 60$ & $2826(2718) 2494$ \\
\hline A7 & 9 & $32.4-37$ & Wk-3938 & shell $^{\mathrm{a}}$ & 81.2 & $2720 \pm 60$ & $2681(2370) 2283$ \\
\hline The Granites & $11 \mathrm{M}$ & $45.5-52.1$ & Wk-3941 & shell $^{\mathrm{a}}$ & 71.3 & $2680 \pm 60$ & $2598(2339) 2188$ \\
\hline The Granites & $11 \mathrm{C}$ & $45.5-52.1$ & Wk-3940 & shell $^{\mathrm{b}}$ & 66.7 & $3260 \pm 70$ & $3304(3075) 2865$ \\
\hline White Patch & 4 & $12.8-18.4$ & Wk-3942 & shell $^{\mathrm{a}}$ & 79.6 & $2440 \pm 80$ & $2307(2071) 1861$ \\
\hline White Patch & 10 & $37.6-44.8$ & Wk-3943 & shell $^{\mathrm{a}}$ & 74.8 & $2570 \pm 60$ & $2358(2273) 2057$ \\
\hline
\end{tabular}

Anadara trapezia

b Mixed shell consisting of Saccostrea sp., Polynices sp., Nerita chamaeleon, Placamen calophyllum, Fragum hemicardium, Gafrarium australe, Cymatium sp., Corbula sp., Antigona chemnitzii, Trisidos tortuosa, Tapes dorsatus, Meropesta sp., Pinctada sp., Trichomya hirsuta, Bembicium auratum, Calthalotia arruensis and Anadara trapezia.

\section{Chronology}

Radiocarbon dates from the deposits at the Mort Creek Site Complex suggest Aboriginal occupation in this region before 2,300 cal BP (Lilley et al. 1996) (Table 1; see Ulm and Lilley this volume:Appendix $\mathrm{C}$ for full details). Conventional radiocarbon ages are corrected for ${ }^{13} \mathrm{C} /{ }^{12} \mathrm{C}$ fractionation and were calibrated using the CALIB (v3.0.3c) computer program (Stuiver and Reimer 1993). Dates on marine shell samples were calibrated using the marine calibration dataset of Stuiver and Braziunas (1993) with a $\Delta R$ correction value of $-5 \pm 35$. The calibrated ages reported span the $2 \sigma$ calibrated age-range. This $\Delta R$ value is based on open ocean values established by Gillespie and Temple (1977, see also Gillespie and Polach 1979). Although the Mort Creek Site Complex is located on a creek margin, the Mort Creek estuary can essentially be considered as part of the extensive Rodds Harbour which has a high tidal range and consequent high tidal flushing. The local marine reservoir effect is, therefore, likely to be similar to the open water value of $-5 \pm 35$ (Spennemann and Head 1996).

All samples are of the mud ark Anadara trapezia except Wk-3940, which is a mixed sample of several bivalve species. As Anadara is an aragoniticsecreting organism, all radiocarbon samples were subject to $\mathrm{X}$-ray diffraction analysis (XRD) by the Waikato Radiocarbon Laboratory prior to dating to test for possible recrystallisation. Several samples submitted for determination from The Granites were rejected on this basis.

The Granites XU11C (Wk-3940) dates the surface of a buried chenier ridge while The Granites XU11M
(Wk-3941) dates suspected midden material lying directly on top of the chenier. The shells were separated on the basis of colour staining and the colour and texture of the matrix adhering to the specimens of shell (Lilley et al. 1996:39). Like the shell from the White Patch chenier, The Granites chenier was characterised by pink-tinged shell and clean yellow sand, whereas shell from the midden deposit was defined by a lack of pink colouration of the shell and by the fine, dark, organic sediment adhering to it (Lilley et al. 1999).

The two White Patch determinations (Wk-3942 and Wk-3943) date the chenier deposit southwest of The Granites, suggesting that it was forming while the lower Granites midden was being deposited on the surface of chenier formed centuries earlier. The dates obtained from $\mathrm{A} 7$ indicate formation of this deposit between c.2,400-2,800 cal BP. The apparent inversion of the date from XU9 (Wk-3938) may simply indicate rapid formation of the deposit as all three determinations overlap at the two sigma calibrated age-range. Thus the radiocarbon dates suggest an overlap in the formation of cultural and natural shell deposits in the study area. This interfingering of chronology adds further ambiguity to the status of A7.

\section{Analytical Premises and Procedures}

The problem in the Mort Creek investigations thus became one of accurately distinguishing chenier material from shell midden deposit and deciphering the depositional history of each excavation.

In Australian coastal archaeology there exists a substantial list of criteria which are conventionally 
used to distinguish the nature and formation of cultural and natural shell formations (e.g. Attenbrow 1992; Bailey 1994; Gill 1954; McNiven 1996). Some of these criteria include the presence or absence of cultural materials such as charcoal, bone and stone artefacts and evidence for size selection in so-called 'economic' species. For some time, however, it has been recognised that these criteria are not always reliable in accurately distinguishing midden shell deposits from natural shell deposits such as cheniers (Bailey 1994; O'Connor and Sullivan 1994; Rowland 1994; Sullivan and O'Connor 1993). More recently, the technique of foraminifera analysis has been used to aid in the identification of cultural shell deposits (Gill et al. 1991; Lilley et al. 1999; McNiven 1996).

\section{Foraminifera Analysis}

Foraminifera (forams) are microscopic organisms that have calcium carbonate exoskeltons known as 'tests'. They are ubiquitous and abundant in marine environments. By assessing their abundance in shell deposits, archaeologists can determine the degree to which seawater was involved in the formation of a shell deposit. Theoretically, this enables natural shell accumulations, middens re-worked by seawater and in situ shell midden deposits to be distinguished. The technique has been applied to archaeological deposits on only three occasions, initially by Gill et al. (1991), then by McNiven (1996) and most recently by Lilley et al. (1999). Gill et al. (1991) recognised that the presence or absence of foraminifera in coastal shell deposits could provide insights into the influence of the sea on site formation. As forams are abundant in seawater, they tend to be extremely common in sediment laid-down or re-worked by wave action (McNiven 1996). Hence, it was hypothesised, foraminifera tests should be present in any deposit laid down or re-worked by seawater, but not in middens which have not been inundated by seawater (Gill et al. 1991). Lilley et al. (1999) note, however, that foraminifera may be present in the matrix of an in situ midden which was deposited on, or covered by, wind- or water-borne marine sediment or where seawater has been transported to the site by humans. If this were the case, they suggest that although forams will be present, they should be very considerably fewer in number in midden deposits than in natural marine sediments.

Thus, various hypotheses had to be tested regarding the application of foraminifera analysis to the Mort Creek Site Complex deposits. First, to provide initial confirmation of the utility of the technique, Lilley et al. (1999) had to demonstrate that control samples obtained from the beach, the chenier ridge samples and the material excavated at White Patch contained foraminifera, while a sample obtained from the midden at The Granites did not. Second, assuming confirmation of the effectiveness of the technique in these relatively unambiguous cases, the status of A7 as a midden could be tested by determining whether or not it contained foraminifera (Lilley et al. 1999).

As anticipated, the sediment from the control samples and White Patch revealed abundant foraminifera, while that from the upper, definitelycultural unit of The Granites contained none. The results were taken "as preliminary confirmation of the validity of foraminiferal analysis as a test of the human origins of shell deposits in the study area" (Lilley et al. 1999:13). The sediment analysed from A7 (extracted from XU5) also had no observable foraminifera content. On the basis of this finding, coupled with the results from the other samples, the presence of a suspected shell artefact (Culbert 1996) and the apparently size-selected Anadara trapezia shells in the excavation, A7 was concluded to be a midden (Lilley et al. 1999).

To test further these preliminary conclusions, an in-depth analysis of material from each excavation was conducted (Carter 1997). This investigation employed two of the major criteria used in Australian midden studies - species diversity and intra-specific size. These criteria respectively specify that shell middens will contain a restricted range of species, predominantly of larger sizes, whilst natural accumulations such as cheniers will contain a large number of species, and exhibit a larger proportion of small shells.

\section{Sampling}

Sampling was necessary owing to the large amount of material extracted from the excavations. The two elements which influenced the sampling strategy were the time available for analyses and the nature of the deposits themselves. The Granites deposit consisted of 13 excavation units, all of which were sorted and analysed. There were 10 excavation units (XUs) dug at White Patch. Owing to the large volume of shell that was recovered, the sample of material sorted from this test pit included all coarse $(6 \mathrm{~mm})$ sieve residues from XUs 1, 5 and 8 . These XUs represent a sample of each of the three different depositional units observed during excavation (Figure 6). Owing to the great bulk of fine sieve $(3 \mathrm{~mm})$ residues collected, sorting of a $100 \%$ sample was not feasible. Consequently, a random sample of $100 \mathrm{~g}$ of fine sieve residue from each of the three selected White Patch XUs was chosen for analysis. The excavation at A7 consisted of $14 \mathrm{XUs}$. No material at all was retained by the field crew from XUs 1-2, as these units contained only sand. The remaining 12 units were all analysed. All coarse sieve $(6 \mathrm{~mm})$ residues were 
sorted. All fine sieve residues were analysed with the exception of residues in excess of $100 \mathrm{~g}$, where only a $100 \mathrm{~g}$ sample was studied.

\section{Laboratory Procedures}

Owing to several methodological requirements for the sizing of individual shells within species (intraspecific size selection), the NISP (Number of Identified Specimens) and weight methods were rejected for the calculation of relative shellfish abundances (see Carter 1997 for more detailed information regarding methodology). MNI (Minimum Number of Individuals) was the method selected for characterizing shell abundance. The rationale for this selection is summarised by Bowdler (1983:140).

For each sampled excavation unit from each area, all molluscs were identified and analysed according to species. Each shell was identified using specific diagnostic features, such as the umbo or hinge of a bivalve and the columella (the inner lip of the anterior opening) of gastropods. MNI calculations for each species were conducted using specific structural elements or parts of a shell. Bivalve MNIs, for example, were calculated by counting the highest frequency of right or left umbos or valves. For gastropods, apertures or opecular openings were used as diagnostic elements of individual specimens. Table 2 defines the classifications of shellfish remains devised for analysis of molluscan remains.

For each site and for each excavation unit, the size-classing of individuals was conducted for all species. This was carried out using only whole shells (see Table 2). Seven categories of size-classes were employed: 0-10mm, 11-20mm, 21-30mm, 31-40mm, $41-50 \mathrm{~mm}$ and $>60 \mathrm{~mm}$. Shells were categorised using a size chart drawn on $1 \mathrm{~mm}$ graph paper.

A limited analysis of non-molluscan remains from each of the deposits was also conducted. Small quantities of fish bone, stone artefacts and ochre were identified in the top half of The Granites. White Patch contained a single unburnt fish vertebra and very small crab remains as well as unmodified stone and coral fragments. A7 contained small quantities of fish bone in XUs 3-4. Both The Granites and A7 contained small quantities of charcoal. Carter (1997) provides details. A summary of analytical results for each excavation square is presented here as Appendix B-D.

Table 2. Categories of shellfish remains for the analysis of molluscan remains.

\begin{tabular}{|c|c|}
\hline Shell Type & Definition \\
\hline \multicolumn{2}{|l|}{ BIVALVES } \\
\hline Whole shell & A valve completely $(100 \%)$ intact displaying the entire valve and umbo \\
\hline Broken shell & Any valve which is not completely intact but displays $>50 \%$ of the umbo \\
\hline Fragment & Any part of the valve which displays $<50 \%$ of the umbo \\
\hline \multicolumn{2}{|c|}{ OYSTERS and like species } \\
\hline Whole shell & A base or lid completely $(100 \%)$ intact displaying the hinge \\
\hline Broken shell & A base or lid which is not completely intact but displays $>50 \%$ of the hinge \\
\hline Fragment & Any part of the valve which displays $<50 \%$ of the hinge \\
\hline \multicolumn{2}{|c|}{ LARGE GASTROPODS ${ }^{\text {a }}$} \\
\hline Whole shell & Any shell which is completely $100 \%$ intact and displays the aperture \\
\hline Broken shell & Any part of the shell which displays an aperture $>50 \%$ complete \\
\hline Fragment & Any part of the shell which displays $<50 \%$ of the aperture \\
\hline \multicolumn{2}{|c|}{ SMALL GASTROPODS ${ }^{b}$} \\
\hline Whole shell & Any shell which is completely intact $(100 \%)$ and/or displays $100 \%$ of the opercular opening and anterior margin \\
\hline Broken shell & Any part of the shell which displays an opercular opening and anterior margin $>50 \%$ complete \\
\hline Fragment & Any part of the shell which displays an opercular opening and anterior margin $<50 \%$ complete \\
\hline
\end{tabular}

a Includes the whelks (e.g. Pyrazus ebeninus, Cerithidae sp. etc., and also Nassirius sp.)

b Includes the small species such as Nerites and cap-shaped gastropods (e.g. Austrocochlea sp., Thalotia sp.). 
Table 3. Number of species per analysed XU in The Granites, White Patch and A7 (NA=Not Available).

\begin{tabular}{|c|c|c|c|c|c|c|c|c|c|c|c|c|c|c|}
\hline Square/XU & $\mathbf{1}$ & $\mathbf{2}$ & $\mathbf{3}$ & $\mathbf{4}$ & $\mathbf{5}$ & $\mathbf{6}$ & $\mathbf{7}$ & $\mathbf{8}$ & $\mathbf{9}$ & $\mathbf{1 0}$ & $\mathbf{1 1}$ & $\mathbf{1 2}$ & $\mathbf{1 3}$ & $\mathbf{1 4}$ \\
\hline The Granites & 9 & 9 & 5 & 4 & 2 & 0 & 0 & 0 & 0 & 1 & 17 & 60 & 62 & - \\
\hline White Patch & 53 & NA & NA & NA & 62 & NA & NA & 72 & NA & NA & - & - & - & - \\
\hline A7 & NA & NA & 10 & 30 & 30 & 50 & 52 & 45 & 45 & 31 & 46 & 36 & 48 & 46 \\
\hline
\end{tabular}

\section{Results of Analysis \\ Species Diversity}

The criterion of species diversity refers to the number of species of shellfish contained in each analysed excavation unit in each site (Table 3; see Appendix A for a complete list of identified species).

XUs $1-11$ at The Granites contained a small number of species. This is a typical feature of shell midden deposits (Attenbrow 1992; Bailey 1994; Bowdler 1983). The dominant species identified are commonly found in middens, such as mud ark (Anadara trapezia), commercial oyster (Saccostrea commercialis), hairy mussel (Trichomya hirsuta) and hercules club shell (Pyrazus ebeninus). These species occur in mud and estuarine habitats (Coleman 1992).

XU11, however, displays a greater species diversity in comparison to the low numbers identified in the upper XUs. Further, XUs 12-13 contain very large numbers of species. In addition to the four species mentioned above, these units contained the small bivalves Garfrarium australe and Corbula sp., which inhabit littoral muddy sand environments (Lamprell and Whitehead 1992) and small gastropods including Calthalotia arruensis and Neritidae sp. which occur in inshore muddy rocks and mangrove swamps (Coleman 1992; Dance 1992). These very small individual molluscs are unlikely to have been targeted as food resources (cf. Rowland 1994). These results strengthen the proposition that at this location, midden deposits rest directly on top of natural chenier deposits.

The species identified in White Patch, the deposit concluded unequivocally to be chenier, numbered over 50 in each of the three excavation units analysed. The material comprised a large assortment of bivalves and gastropods from a range of habitats including littoral sand, rocky intertidal shores, mud flats, mangrove swamps and intertidal sand flats (Coleman 1992; Dance 1992; Lamprell and Whitehead 1992). The presence of such species diversity in White Patch, a feature not found in the undoubted upper shell midden at The Granites, provides additional confirmation that this deposit is a natural chenier formation.

Analysis of A7, the ambiguous deposit, revealed some interesting results. Only one excavation unit
(XU3) exhibited a species diversity which is typical of cultural deposits, as exemplified in this case by the upper units of The Granites. This unit contained only 10 species including Anadara trapezia, Saccostrea commercialis and Trichomya hirsuta. Each of the remaining units, however, exhibited much greater species diversity (between 30 and 52 species), more typical of natural shell deposits such as White Patch. The identified species include a wide range of bivalves and gastropods from a range of habitats including rocky shores, shell debris and mangroves, though mostly from littoral sand. However, there is notable variation in the species diversity of $\mathrm{A} 7$, and overall, fewer species were identified in this deposit than in White Patch. The results of species diversity analysis clearly underline the intriguing nature of A7.

\section{Intra-Specific Size Selection}

The second criterion for analysis of excavated shell used here is the size selection of species contained in the deposits. For each analysed excavation unit of each site, all whole shells were size-classed into the categories mentioned above. Figure 8 illustrates the results of this analysis. Results presented for the The Granites are twofold. XUs 1-11 comprise mostly shells measuring between $31-40 \mathrm{~mm}(54.87 \%)$. Shells measuring $41-50 \mathrm{~mm}$ form the second largest proportion of molluscan remains. The size-classes 0 $10 \mathrm{~mm}$ and $21-30 \mathrm{~mm}$ comprise less than $10 \%$ of the deposit, whilst material belonging to $11-20 \mathrm{~mm}$ constitutes less than 15\%. Overall, most shells excavated from these units are large individuals measuring greater than $31 \mathrm{~mm}$. Shells of this size are generally classified by Australian researchers as 'economic', or elsewhere defined as 'medium to large adults' (Attenbrow 1992).

Results of size selection analysis of XUs 12-13 of The Granites, however, demonstrate something quite different (Figure 8, 9). In these lower units, the majority of the shell assemblage consists of individuals measuring $11-20 \mathrm{~mm}(53.84 \%)$, followed by those measuring $21-30 \mathrm{~mm}(14.94 \%)$. Individuals classed above $31 \mathrm{~mm}$ constitute less than $20 \%$ of the shell deposit. These results clearly confirm the existence of a chenier at the base of The Granites excavated deposit. 
As illustrated in Figure 8, analysis of size selection in White Patch revealed results diametrically opposite to those from XUs 1-11 in The Granites. In White Patch, over $60 \%$ of shell was sizeclassed $11-20 \mathrm{~mm}$. The second largest proportion of shell measures to the smallest size-class, $0-10 \mathrm{~mm}$ $(24.75 \%)$. The remaining size-classes $(21-30 \mathrm{~mm}, 31$ $40 \mathrm{~mm}, 41-50 \mathrm{~mm}, 51-60 \mathrm{~mm}$ and $>60 \mathrm{~mm}$ ) together constitute less than $10 \%$ of the shellfish remains in the square. These results are very similar to those from the lower units of The Granites excavation. On the basis of these findings, the preliminary conclusion concerning the natural origin of White Patch is confirmed.

The size-class analysis of individuals from A7 produced ambiguous results. As Figure 8 shows, although the most common size-class is $0-10 \mathrm{~mm}$ $(26.52 \%)$, there is little variation between the four smallest size-classes, with $11-20 \mathrm{~mm}, 21-30 \mathrm{~mm}$ and $31-40 \mathrm{~mm}$ occurring in similar proportions to the 0 $10 \mathrm{~mm}$ size-class $(22.67 \%, 21.15 \%$ and $20.81 \%$ respectively). The remaining size-classes $(41-50 \mathrm{~mm}$, $51-60 \mathrm{~mm}$ and $>60 \mathrm{~mm}$ ) each constitute less than $10 \%$ of individuals in the A7 excavation. Thus, based on the results of intra-specific size selection, A7 appears to be more similar to White Patch than to The Granites (XUs 1-11), in that it contains a majority of small, perhaps juvenile, shells. As noted, however, the proportions at which shells measuring $11-20 \mathrm{~mm}$, $21-30 \mathrm{~mm}$ and $31-40 \mathrm{~mm}$ occur in $\mathrm{A} 7$ are almost equal to the proportions of shells $0-10 \mathrm{~mm}$. This feature is not apparent in White Patch or The Granites shell assemblages.

Figure 9 illustrates the size-class distribution of selected excavation units of The Granites. XUs 4-10 are not included as they contained negligible quantities of shellfish remains (see Appendix D). In XUs 1-3 the size-class $31-40 \mathrm{~mm}$ contains the highest number of individuals. In XUs 2-3 the size-class 31$40 \mathrm{~mm}$ contains significantly more individuals than the class $41-50 \mathrm{~mm}$. XU11, on the other hand, exhibits a considerable difference in size selection in comparison with the top units. In this lower unit, the size-class of $11-20 \mathrm{~mm}$ contains the most individuals, followed by the smallest size-class, $0-10 \mathrm{~mm}$. The remaining, larger size-classes each contain less than 10 individuals. A broader species-diversity in XU11 of The Granites was indicated earlier, and interpreted as confirmation that this unit contains both cultural and natural shell deposits (see Table 3). Evidence for a more varied intra-specific size selection in this XU further supports this interpretation. XUs 12-13, however, are clearly dominated by individuals measuring $11-20 \mathrm{~mm}$. This distribution in size-classes is exhibited by the White Patch chenier. These results confirm the lower units in The Granites as chenier.
The analysis of the intra-specific size selection in A7 produced some intriguing results (Figure 10). First, the top half of the excavation (XUs 3-7) is dominated by larger individuals measuring $31-40 \mathrm{~mm}$. Intra-specific size selection in XUs 1-3 of The Granites also exhibits this feature. Unlike these units of The Granites, however, the top of the A7 deposit evinces a gradual increase with depth of individuals less than $30 \mathrm{~mm}$ in size.

Second, in XU7 the smallest size-classes, particularly $0-10 \mathrm{~mm}$ and $11-20 \mathrm{~mm}$, occur in almost equal numbers to that in the $31-40 \mathrm{~mm}$ size-class. $\mathrm{XU}$ 8, however, indicates a distinct changeover, being clearly dominated by individuals measuring $0-10 \mathrm{~mm}$.

Third, apart from XU12, the remaining units of A7 are dominated by shells measuring $0-10 \mathrm{~mm}$ and 11 $20 \mathrm{~mm}$. Thus the bottom half of the excavation appears to be similar in terms of shell size to material found in White Patch. In contrast, however, XU12 is dominated by shells of the larger size-classes, 21$30 \mathrm{~mm}$ and $31-40 \mathrm{~mm}$.

\section{Summary}

Based on the results obtained from the analysis of species diversity and intra-specific size selection in The Granites and White Patch, their origins and depositional contexts were determined. The majority of excavation units in The Granites contained shell midden deposit, with the bulk of cultural material occuring in the upper section of the excavation. As field observations suggested, the lower units comprised of a thin layer of cultural shellfish remains resting directly on top of a natural chenier formation. The analysed excavation units of White Patch undoubtedly confirmed its natural origin, comprising hundreds of juvenile shells representing a diverse range of species.

The results of analysis also clearly defined the complex nature of A7. This deposit consists of both in situ shell midden and chenier deposit and reworked deposits. Based on the results of both criteria of analysis, the following depositional content of A7 is proposed:

- XU3 - in situ shell midden;

- XUs 4-6 - mixed deposit containing mostly cultural shell midden material;

- XU7 - mixed deposit containing mostly chenier material;

- XUs 8-11 in situ chenier;

- XU12 - mixed deposit containing mostly chenier material; and,

- XUs 13-14 chenier.

This intricate depositional content of A7 has implications for the results and efficacy of foraminifera analysis. 

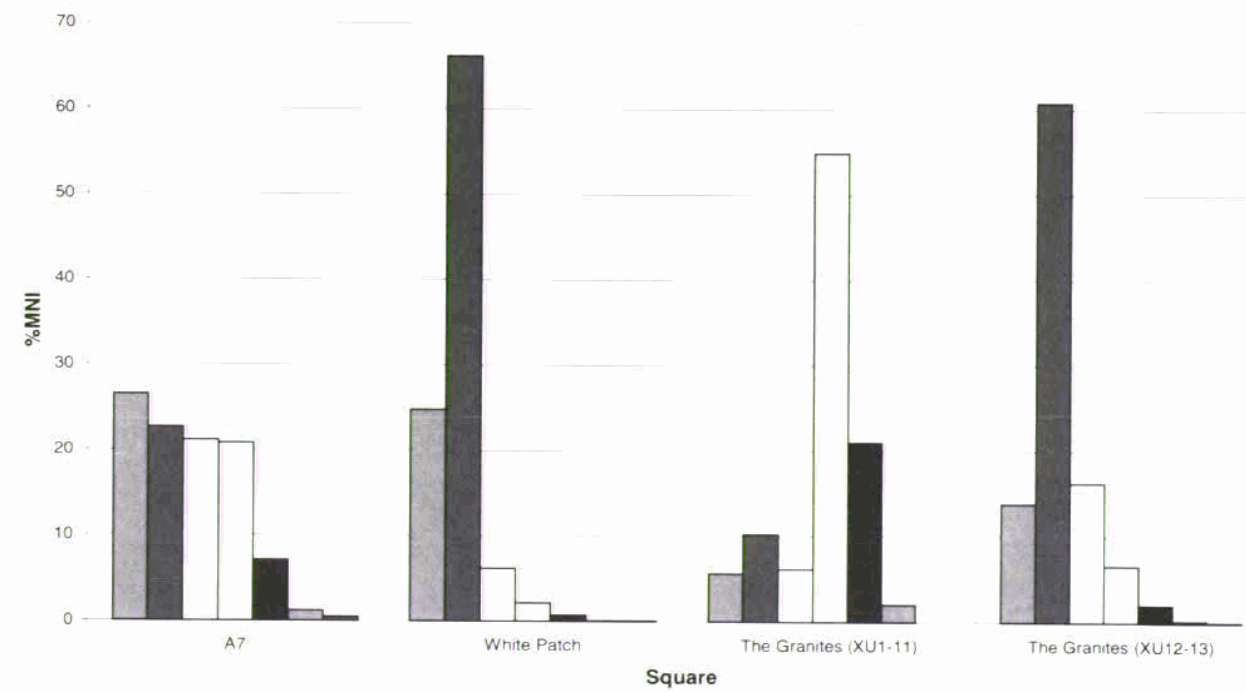

Figure 8. \% MNI for size-classes in A7, White Patch and The Granites (XUs 1-11 and XUs 12-13).

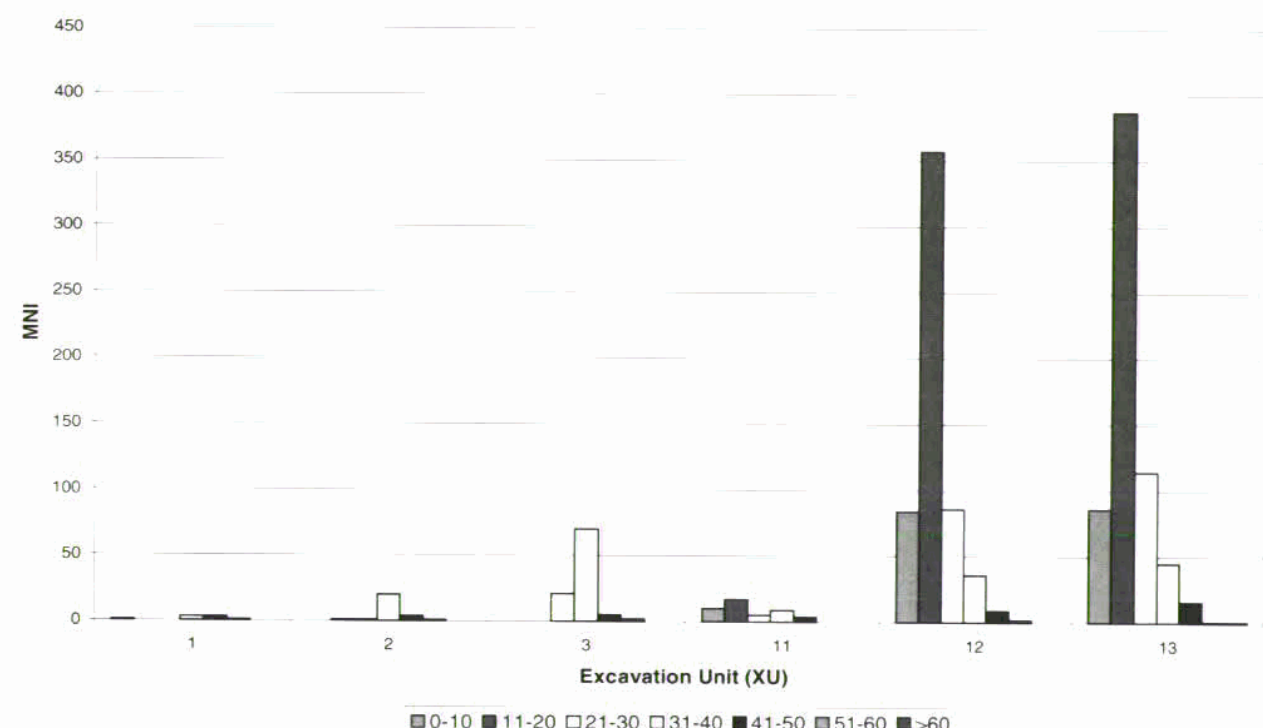

Figure 9. MNI for size-classes in selected XUs of The Granites.

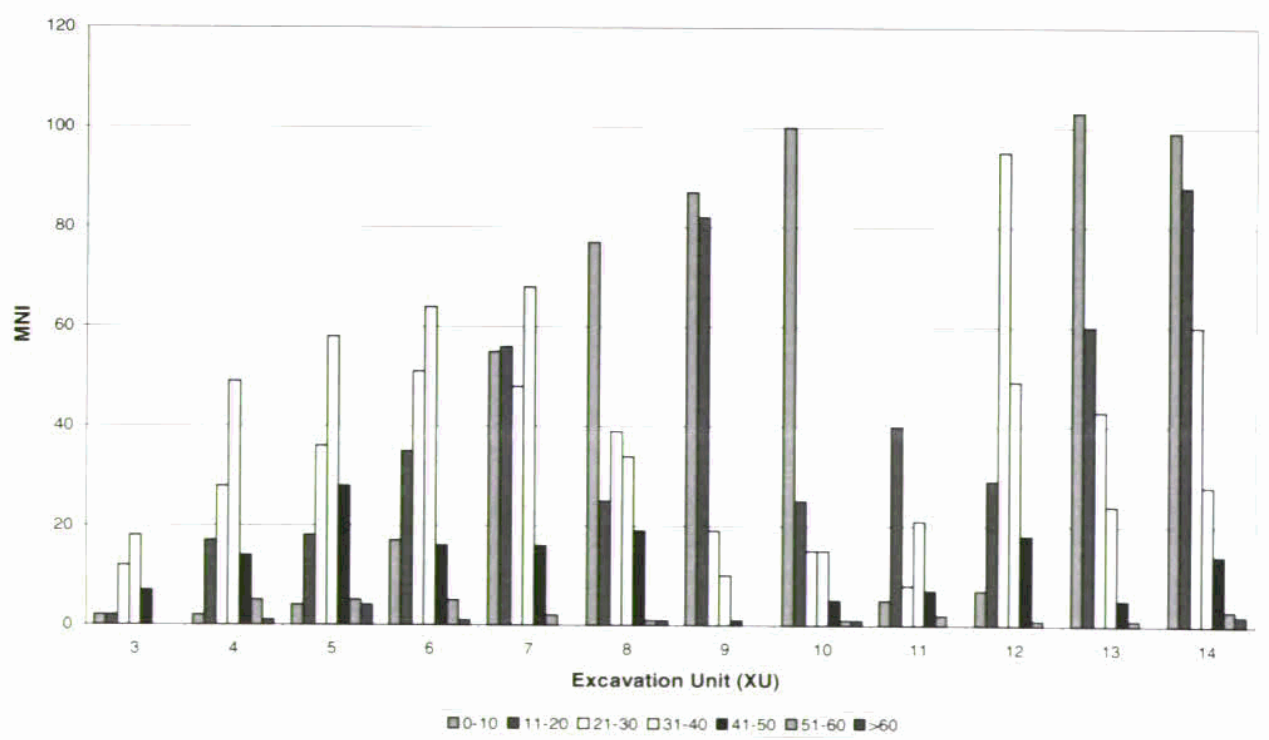

Figure 10. MNI for size-classes in analysed XUs of A7. 


\section{Discussion}

\section{Foraminifera Analysis}

For each of the Mort Creek Site Complex excavations, foraminifera analysis was conducted using only one sediment sample, representing only one stratigraphic unit from each locality. For White Patch and The Granites, the results obtained by foraminifera analysis were sufficient to affirm the preliminary conclusions established through the more conventional criteria of identification, because each of these deposits was relatively homogenous. On the other hand, the results for A7 may be regarded as equivocal, as this deposit exhibited marked heterogeneity in the vertical structure of the deposit. Thus, any diagnosis based on one sediment sample from one excavation unit in A7 is problematic and insufficient (Carter 1997; Lilley et al. 1999). Analysis of numerous sediment samples taken throughout the deposit may have provided some insight into the complicated nature of $\mathrm{A} 7$ which is illustrated by the results of more conventional criteria of analysis.

\section{Coastal Processes and Site Formation}

A major aim of the Gooreng Gooreng Cultural Heritage Project is to establish the degree to which an apparent concentration of sites along estuaries and their absence on ocean beaches "reflects past Aboriginal behaviour, recent geological processes or patterns of archaeological research" (Lilley and Ulm 1995:12). The findings detailed in this report suggest that all three factors may be influential.

Chenier deposits are relatively common on northern Australian coasts, including those in Central Queensland (Chappell and Grindrod 1984). They are generally mid-to-late Holocene features, having developed following the post-glacial rise in sea-level about 6,000 BP (Chappell and Grindrod 1984; O'Connor and Sullivan 1994; Short 1989). Owing to their elevation and adequate drainage, cheniers are often interpreted as occupation locations preferred by Aborigines over poorly-drained, low-lying coastal plains (Chappell and Grindrod 1984; Sullivan and O'Connor 1993). Accordingly, the discovery of middens overlying cheniers is not uncommon in coastal investigations (e.g. Beaton 1985; Lilley et al. 1999; O'Connor and Sullivan 1994). The presence of midden deposits on top of chenier formations in both The Granites and A7 is testimony to this archaeological phenomenon in the study area. The Mort Creek Site Complex deposits indicate that after cheniers were deposited they were occupied by Aboriginal people, sometimes for only relatively short periods of time, after which further chenier material was laid down.

The archaeological investigations reported here confirm that the interaction between humans and environment is multi-dimensional and complex and can result in localised co-existence and inter-mixing of natural and cultural shell deposits. This has often led to the misidentification of shell deposits by archaeologists (Bonhomme and Buzer 1994; Sullivan and O'Connor 1993:776). Our results suggest considerable work is required on a local, case-by-case basis to minimize such problems.

\section{Conclusions}

On the basis of this study, several observations can be offered regarding the nature and distribution of shell deposits in the Rodds Peninsula area:

1. There are extensive natural marine shell deposits in the area, mostly in the form of cheniers. Analysis of excavated deposits reveal that they contain a wide range of marine bivalve and gastropod species, predominantly of small and juvenile sizes. These natural deposits may also contain large proportions of commercial oyster (Saccostrea commercialis). Cheniers occur in both surface and subsurface contexts;

2. There are undisturbed shell middens in the region. These may be exposed on the surface or occur as subsurface deposits completely covered by sediment. The deposits will generally contain a restricted range of species dominated by larger individuals. The mud ark (Anadara trapezia) may occur as the dominant species. Other cultural remains such as charcoal, fish bone, and stone artefacts may also be present in small amounts. Undisturbed shell middens may occur directly on top of cheniers, in such a way that midden material lies amongst natural shell; and,

3. There are re-worked or mixed shell middens in the area. These also may be exposed or occur below the surface. The deposits will contain a greater diversity of species and an increase in the number of small or juvenile shells. Mud ark (Anadara trapezia) may still occur as the dominant species. Charcoal, fish bone and stone artefacts will rarely be present. Re-worked shell middens may also occur on top of cheniers.

\section{Acknowledgments}

We thank Ron Johnson (Sr) and Ron Johnson (Jr), representing the Gurang Land Council Aboriginal Corporation, for collaborating in the Mort Creek fieldwork under trying conditions. We are particularly grateful to John Jell (University of Queensland), who advised us on protocols for foraminifera examination and to Colin Campbell (Australian National University) who suggested numerous useful references on the topic. Ian McNiven (University of Melbourne) suggested that we look for forams in our middens in the first place. John Richter participated 
in the excavations and drew Figures 1-2 and 5-7. Thanks are also due to Thora Whitehead and Terry Carless (Invertebrate Zoology, Queensland Museum) for identifying numerous shells that defied our reference collection. Funding for fieldwork was provided by the National Estate Grants Program and the Aboriginal and Torres Strait Islander Studies Unit at the University of Queensland. Both the Department of Sociology, Anthropology and Archaeology and the Aboriginal and Torres Strait Islander Studies Unit at the University of Queensland provided laboratory facilities for this research. Jill Reid (Aboriginal and Torres Strait Islander Studies Unit, University of Queensland) checked data tables and commented on several drafts.

\section{References}

Attenbrow, V. 1992 Shell bed or shell midden. Australian Archaeology 34:3-21.

Bailey, G. 1994 The Weipa shell mounds: Natural or cultural. In M. Sullivan, S. Brockwell and A. Webb (eds), Archaeology in the North: Proceedings of the 1993 Australian Archaeological Association Conference, pp.107-129. Darwin: North Australia Research Unit, Australian National University.

Beaton, J.M. 1985 Evidence for a coastal occupation timelag at Princess Charlotte Bay (North Queensland) and implications for coastal colonisation and population growth theories for Aboriginal Australia. Archaeology in Oceania 20(1):1-20.

Bonhomme, T. and S. Buzer 1994 Holocene Shell Middens of the Central Coast of New South Wales: An Investigation of the Management Problems Concerning Coastal Shell Middens. Unpublished report to the New South Wales National Parks and Wildlife Service, Sydney.

Bowdler, S. 1983 Sieving seashells: Midden analysis in Australian archaeology. In G. Connah (ed.), Australian Field Archaeology: A Guide to Techniques, pp.135144. Canberra: Australian Institute of Aboriginal Studies.

Burke, C. 1993 A Survey of Aboriginal Archaeological Sites on the Curtis Coast, Central Queensland. Unpublished report to the Queensland Department of Environment and Heritage, Rockhampton.

Carter, M. 1997 Chenier and Shell Midden: An Investigation of Cultural and Natural Shell Deposits at Rodds Peninsula, Central Queensland Coast. Unpublished B.A. (Hons) thesis, Department of Anthropology and Sociology, University of Queensland, Brisbane.

Chappell, J. and J. Grindrod 1984 Chenier plain formation in northern Australia. In B. Thom (ed.), Coastal Geomorphology in Australia, pp.197-231. Sydney: Academic Press.

Coleman, N. 1992 What Shell is That? Sydney: Ure Smith Press.
Culbert, N. 1996 An Analysis of a Suspected Shell Artefact from Rodds Peninsula, Central Queensland Coast. Unpublished report submitted for AY269 Independent Study 1, Department of Anthropology and Sociology, University of Queensland, Brisbane.

Dance, S.P. 1992 Shells: A Visual Guide to Over 500 Species of Seashell from Around the World. Pymble: Harper Collins Publishers.

Gill, E. 1954 Aboriginal kitchen middens and marine shell beds. Mankind 4:249-254.

Gill, E., J. Sherwood, J. Cann, P. Coutts and C. Magilton 1991 Pleistocene shell beds of the Hopkins River, Warrnambool, Victoria: Estuarine sediments or Aboriginal midden? In M. Williams, P. De Dekker and P. Kershaw (eds), The Cainozoic in Australia: $A$ Reappraisal of the Evidence, pp.321-338. Special Publication 18. Sydney: Geological Society of Australia.

Gillespie, R. and H.A. Polach 1979 The suitability of marine shells for radiocarbon dating of Australian prehistory. In R. Berger and H.E. Suess (eds), Radiocarbon Dating: Proceedings of the Ninth International Conference, Los Angeles and La Jolla 1976, pp.404-421. Berkeley: University of California Press.

Gillespie, R. and R.B. Temple 1977 Radiocarbon dating shell middens. Archaeology and Physical Anthropology in Oceania 12:26-37.

Lamprell, K. and T. Whitehead 1992 Bivalves of Australia. Vol. 1. Bathurst: Crawford House Press.

Lilley, I. and S. Ulm 1995 The Gooreng Gooreng Cultural Heritage Project: Some proposed directions and preliminary results of the archaeological program. Australian Archaeology 41:11-15.

Lilley, I., S. Ulm and D. Brian 1996 The Gooreng Gooreng Cultural Heritage Project: First radiocarbon determinations. Australian Archaeology 43:38-40.

Lilley, I., D. Brian and S. Ulm 1999 The use of foraminifera in the identification and analysis of marine shell middens: A view from Australia. In M-J. Mountain and D. Bowdery (eds), Taphonomy: the Analysis of Processes from Phytoliths to Megafauna, pp.9-16. Research Papers in Archaeology and Natural History 30. Canberra: Archaeology and Natural History Publications, Research School of Pacific and Asian Studies, Australian National University.

Lilley, I., M. Williams and S. Ulm 1997 The Gooreng Gooreng Cultural Heritage Project: A Report on National Estate Grants Program Research, 1995-1996. 2 vols. Brisbane: Aboriginal and Torres Strait Islander Studies Unit, University of Queensland.

McNiven, I. 1996 Mid- to late Holocene shell deposits at Hibbs Bay, southwest Tasmania: Implications for Aboriginal occupation and marine resource exploitation. In J. Allen (ed.), Report of the Southern Forests Archaeological Project: Site Descriptions, Stratigraphies and Chronologies, pp.219-47. Vol. 1. Bundoora: School of Archaeology, La Trobe 
University.

O'Connor, S. and M. Sullivan 1994 Distinguishing middens and cheniers: A case study from the southern Kimberley. Archaeology in Oceania 29(1):16-28.

Rowland, M.J. 1994 Size isn't everything: Shells in mounds, middens and natural deposits. Australian Archaeology 39:118-124.

Short, A. 1989 Chenier research on the Australian coast. Marine Geology 90:345-351.

Spennemann, D.H.R. and M.J. Head 1996 Reservoir modification of radiocarbon signatures in coastal and near-shore waters of eastern Australia: The state of play. Quaternary Australasia 14(1):32-39.
Stuiver, M. and T.F. Braziunas 1993 Modeling atmospheric ${ }^{14} \mathrm{C}$ influences and ${ }^{14} \mathrm{C}$ ages of marine samples to 10,000 BC. Radiocarbon 35(1):137-189.

Stuiver, M. and P.J. Reimer 1993 Extended ${ }^{14} \mathrm{C}$ data base and revised CALIB $3.0{ }^{14} \mathrm{C}$ age calibration program. Radiocarbon 35(1):215-230.

Sullivan, M. and S. O'Connor 1993 Middens and cheniers: Implications for Australian research. Antiquity 67:776788.

Ulm, S. and I. Lilley this volume The archaeology of the southern Curtis Coast: An overview. Queensland Archaeological Research 11. 
Appendix A. Mort Creek Site Complex, Shell Species per Square ${ }^{\mathrm{a}}$.

\begin{tabular}{|c|c|c|c|c|c|}
\hline Species Name & Common Name & Habitat & A7 & White Patch & The Granites \\
\hline $\begin{array}{l}\text { Acrosterigma } \\
\text { reeveanum }\end{array}$ & Flavum heart cockle & muddy sand & $x$ & $x$ & $\mathrm{X}$ \\
\hline $\begin{array}{l}\text { Acrosterigma } \\
\text { rosemariensis }\end{array}$ & & littoral sand & $\mathrm{x}$ & & \\
\hline Afrocardium skeeti & & coral sand & $\mathrm{X}$ & & \\
\hline Anodontia bullula & & coral sand & $\mathrm{X}$ & $\mathrm{X}$ & \\
\hline Anodontia endentula & & littoral mangroves & $x$ & & \\
\hline Anodontia pila & & littoral mangrove areas & & $\mathrm{X}$ & \\
\hline Anadara granosa & Cockle & mangroves & & $\mathrm{X}$ & \\
\hline $\begin{array}{l}\text { Anadara } \\
\text { rotundiscostata }\end{array}$ & Cockle & mangroves & & $x$ & $X$ \\
\hline Anadara trapezia & Mud ark & mud/estuary & $\mathrm{X}$ & $X$ & $\mathrm{X}$ \\
\hline Antigona chemnitzi & & littoral sand & $\mathrm{X}$ & $\mathrm{X}$ & \\
\hline Antigona lamellaris & & littoral sand & $\mathrm{X}$ & $\mathrm{X}$ & \\
\hline $\begin{array}{l}\text { Austrocochlea } \\
\text { constricta }\end{array}$ & Ribbed periwinkle & estuary & $\mathrm{X}$ & $X$ & \\
\hline Austrocochlea sp. & Periwinkle & rocky shores & $\mathrm{X}$ & & \\
\hline Azorinus minutus & & littoral sand & & $x$ & \\
\hline Bembicium auratum & $\begin{array}{l}\text { Gold-mouthed topped } \\
\text { shell }\end{array}$ & rocky intertidal shores & $X$ & $X$ & $\mathrm{X}$ \\
\hline Bendeva hanleyi & Hanley's oyster drill & rocky shores/mangroves & $x$ & $X$ & $X$ \\
\hline Calthalotia arruensis & Periwinkle & rocky shores & $x$ & $\mathrm{X}$ & \\
\hline Cardita incrassata & Thickened cardita & rocky/coral shores & $\mathrm{X}$ & $\mathrm{X}$ & \\
\hline Cerithium anticipata & Sand creeper & sand & & $\mathrm{X}$ & \\
\hline Cerithium cingulata & Sand creeper & sand & $X$ & $X$ & \\
\hline Chlamys sp. & & rocks/coral & & $x$ & \\
\hline Chama fibula & & shell and coral debris & $\mathrm{X}$ & $\mathrm{X}$ & $X$ \\
\hline Chama limbula & & $\begin{array}{l}\text { rock platforms/coral } \\
\text { platforms }\end{array}$ & & $\mathrm{X}$ & \\
\hline Chama pulchella & & shell debris & $X$ & & \\
\hline Chama sp. & & shell debris & $x$ & & \\
\hline Chicoreus denudatus & Denuded murex & rocky reefs & $\mathrm{X}$ & $x$ & \\
\hline Corbula cf. crassa & & sand/mud & & $x$ & \\
\hline Corbula macgillivrayi & & unknown & $\mathrm{X}$ & $x$ & \\
\hline Corbula sp. & & sand/mud & $x$ & $\mathrm{X}$ & \\
\hline $\begin{array}{l}\text { Cycladicama } \\
\text { sphaericula }\end{array}$ & & littoral mud & $x$ & $x$ & \\
\hline Cypraea lamarckii & Lamarck's cowrie & muddy rocks inshore & $\mathrm{X}$ & $\mathrm{X}$ & \\
\hline
\end{tabular}




\begin{tabular}{|c|c|c|c|c|c|}
\hline Species Name & Common Name & Habitat & A7 & White Patch & The Granites \\
\hline Cypraea sp. & & rocks/coral & & $\mathrm{x}$ & \\
\hline Damicar tenebrica & & unknown & $\mathrm{x}$ & $\mathrm{x}$ & \\
\hline Dentaliidae sp. & Tusk shell & sandy mud & $\mathrm{X}$ & $\mathrm{X}$ & \\
\hline Diodora sp. & Limpet & intertidal rocks & $\mathrm{X}$ & $\mathrm{x}$ & \\
\hline Didimacar sculptilis & & unknown & $\mathrm{x}$ & & \\
\hline Donax cuneatus & & littoral sand & & $\mathrm{X}$ & \\
\hline Donax deltoides & Pipi & sand & $\mathrm{X}$ & & \\
\hline Donax faba & & littoral sand & $\mathrm{x}$ & & \\
\hline Donax veruinus & & littoral sand & $\mathrm{X}$ & & \\
\hline Dosinia sculpta & & littoral sand & $\mathrm{X}$ & $\mathrm{x}$ & \\
\hline Ennucula superba & & littoral mud & & $\mathrm{x}$ & \\
\hline Epitonium scalare & Precious wentletrap & subtidal in sand & & $\mathrm{x}$ & \\
\hline Euchelus atratus & Turban shell & rocks/coral reefs & $\mathrm{X}$ & $\mathrm{x}$ & $\mathrm{x}$ \\
\hline Eunaticina papilla & Papilla moon & inshore sand & & $\mathrm{x}$ & \\
\hline Exotica balansae & & littoral sand & & $\mathrm{x}$ & \\
\hline Exotica murrayi & & coral sand & $\mathrm{X}$ & $\mathrm{x}$ & \\
\hline $\begin{array}{l}\text { Fissidentalium } \\
\text { vennedei }\end{array}$ & & unknown & & $\mathrm{x}$ & \\
\hline Fragum hemicardium & Half-cockle & muddy sand & $\mathrm{x}$ & $\mathrm{x}$ & $\mathrm{x}$ \\
\hline Gafrarium australe & & littoral muddy sand & $\mathrm{X}$ & $\mathrm{x}$ & $\mathrm{x}$ \\
\hline $\begin{array}{l}\text { Glycymeris } \\
\text { crebreliratus }\end{array}$ & & sand & & $\mathrm{x}$ & \\
\hline Glycymeris holsericus & & littoral sand & $\mathrm{X}$ & & \\
\hline Gyrineum pusillum & $\begin{array}{l}\text { Purple-mouthed } \\
\text { Kookaburra shell }\end{array}$ & $\begin{array}{l}\text { rocky shores/coral } \\
\text { debris }\end{array}$ & $x$ & & \\
\hline Haustellum haustellum & Snipes head murex & sandy mud & $\mathrm{x}$ & & \\
\hline $\begin{array}{l}\text { Indeterminate } \\
\text { gastropod A }\end{array}$ & & unknown & $\mathrm{X}$ & & \\
\hline $\begin{array}{l}\text { Indeterminate } \\
\text { gastropod B }\end{array}$ & & unknown & $x$ & & \\
\hline Isanda coronata & & unknown & $\mathrm{x}$ & & \\
\hline Isognomon sp. & Pearl shell & litttoral mud & $\mathrm{X}$ & & \\
\hline Leporimetis spectabilis & & littoral sand & $\mathrm{x}$ & $\mathrm{x}$ & \\
\hline Lepsiella vinosa & & intertidal rocks & $\mathrm{x}$ & & \\
\hline Leptonacea sp. & & unknown & $\mathrm{X}$ & & \\
\hline Liotina peronii & Wheel shell & rocky shores/dead coral & & $\mathrm{x}$ & \\
\hline Lippistes blainvillei & & unknown & & $\mathrm{x}$ & \\
\hline Mactra antecedens & & littoral sand & $\mathrm{x}$ & & \\
\hline
\end{tabular}




\begin{tabular}{|c|c|c|c|c|c|}
\hline Species Name & Common Name & Habitat & A7 & White Patch & The Granites \\
\hline Mactra contraria & & littoral sand & $\mathrm{X}$ & & \\
\hline "Mactra" pellucida & & littoral sand & $\mathrm{X}$ & $\mathrm{x}$ & \\
\hline Mactra cf. pusilla & & littoral sand & $\mathrm{X}$ & & \\
\hline Mactra cf. sericea & & littoral sand & $\mathrm{x}$ & $\mathrm{x}$ & \\
\hline Marcia hiantina & & littoral sand & $\mathrm{X}$ & & \\
\hline Melo amphora & Baler shell & mud flats & $\mathrm{x}$ & & \\
\hline Meropesta nicobarius & & littoral sand & $\mathrm{X}$ & $\mathrm{x}$ & \\
\hline Mocoma candida & & sublittoral sand & $\mathrm{X}$ & & \\
\hline Monilea callifera & Top shell & rocky shores & & $\mathrm{X}$ & \\
\hline Morula marginalba & Mulberry shell & rocky reefs & $\mathrm{X}$ & $\mathrm{x}$ & \\
\hline Myadora sp. & & unknown & $\mathrm{X}$ & & \\
\hline $\begin{array}{l}\text { Mysella } \\
\text { spgaleommattacea }\end{array}$ & & unknown & & $\mathrm{x}$ & \\
\hline Nassarius arcularius & & inshore sand and mud & & $\mathrm{X}$ & \\
\hline Nassarius coronatus & Acorn dog whelk & sandy flats & $\mathrm{X}$ & $\mathrm{x}$ & \\
\hline Nassarius dorsatus & Unicolour dog whelk & muddy sand & $\mathrm{X}$ & $\mathrm{x}$ & $x$ \\
\hline Nerita chamaeleon & Nerite & rocky shores & $\mathrm{X}$ & $\mathrm{X}$ & $\mathrm{x}$ \\
\hline Nerita squammata & Nerite & rocky shores & $\mathrm{X}$ & $\mathrm{x}$ & $\mathrm{x}$ \\
\hline Nerita sp. & Nerite & rocky shores & $\mathrm{x}$ & & \\
\hline Nuclana blainvillei & & unknown & & $\mathrm{x}$ & \\
\hline Nuclana cf. electilis & & unknown & $\mathrm{X}$ & & \\
\hline Ophicardelus sp. & & mangrove swamps & & & $\mathrm{x}$ \\
\hline Ostrea sp. & & intertidal mud & $\mathrm{X}$ & & \\
\hline Paphia crassisulca & & littoral sand & $\mathrm{X}$ & $\mathrm{x}$ & \\
\hline Paphia gallus & & littoral sand & $\mathrm{X}$ & $\mathrm{x}$ & \\
\hline Paphia elongata & & beach sand & $\mathrm{X}$ & & \\
\hline Pinctada fucata & Southern pearl shell & littoral mud & & & $\mathrm{x}$ \\
\hline Pinctada sp. & Scallop & muddy flats & $\mathrm{X}$ & $\mathrm{x}$ & \\
\hline Pitar bullatus & & littoral sand & $\mathrm{X}$ & $\mathrm{x}$ & \\
\hline Pitar coxeni & & littoral sand & $\mathrm{X}$ & & \\
\hline Pitar inconstans & & littoral sand & $\mathrm{x}$ & $\mathrm{x}$ & \\
\hline Pitar nipponica & & littoral sand & $\mathrm{X}$ & & \\
\hline Pitar subpellucidae & & littoral sand & $\mathrm{X}$ & & \\
\hline Placamen calophyllum & & littoral sand & $\mathrm{x}$ & $x$ & \\
\hline Placamen tiara & & littoral sand & $\mathrm{X}$ & $\mathrm{x}$ & \\
\hline Plagiocardium setosum & Hairy cockle & muddy sand & $\mathrm{x}$ & $\mathrm{x}$ & \\
\hline Plicatula sp. & Plicate oyster & rocks/coral & $\mathrm{x}$ & $x$ & \\
\hline
\end{tabular}




\begin{tabular}{|c|c|c|c|c|c|}
\hline Species Name & Common Name & Habitat & A7 & White Patch & The Granites \\
\hline Polinices conicus & Moon shell & intertidal sand flats & & $\mathrm{x}$ & \\
\hline Polinices mestamoides & Moon shell & littoral sand/coral reefs & $\mathrm{X}$ & $\mathrm{X}$ & \\
\hline Polinices sordidus & Moon shell & intertidal sand flats & & $\mathrm{X}$ & \\
\hline Polinices sp. & Moon shell & unknown & & $\mathrm{x}$ & \\
\hline Pyrazus ebeninus & Hercules club whelk & mangrove swamps & $\mathrm{X}$ & $\mathrm{X}$ & $\mathrm{X}$ \\
\hline Rhinoclavis asper & & sand & $\mathrm{X}$ & $\mathrm{X}$ & \\
\hline $\begin{array}{l}\text { Saccostrea } \\
\text { commercialis }\end{array}$ & Oyster & $\begin{array}{l}\text { mangroves/mud flats/ } \\
\text { rocky reefs }\end{array}$ & $\mathrm{x}$ & $\mathrm{X}$ & $x$ \\
\hline Scaeochlamys livida & & $\begin{array}{l}\text { littoral rocks/ shell } \\
\text { debris }\end{array}$ & $\mathrm{X}$ & & \\
\hline Semele lamellosa & & littoral sand & $\mathrm{X}$ & $\mathrm{X}$ & \\
\hline Solecurtus sp. & & littoral sand & $\mathrm{x}$ & & \\
\hline Spisula trigonella & & littoral sand & & $\mathrm{X}$ & \\
\hline Spisula sp. & & littoral sand & $\mathrm{X}$ & & \\
\hline Striarca saga & & unknown & $\mathrm{X}$ & $\mathrm{x}$ & \\
\hline Tapes dorsatus & & littoral sand & $\mathrm{X}$ & $\mathrm{X}$ & $\mathrm{x}$ \\
\hline Tawera subnodulosa & & littoral sand & & $x$ & \\
\hline Tellina gemonia & & littoral sand & $\mathrm{X}$ & & \\
\hline Tellina radians & & littoral sand & $\mathrm{X}$ & $\mathrm{X}$ & \\
\hline Tellina robusta & & littoral sand & $\mathrm{X}$ & & \\
\hline Tellina serricostata & & littoral sand & $\mathrm{x}$ & & \\
\hline Tellina tenuilamellata & & littoral sand & & $\mathrm{x}$ & \\
\hline Terebra subulata & & littoral sand & $\mathrm{X}$ & & \\
\hline Terebra sp. & Auger shell & littoral sand & $\mathrm{X}$ & $\mathrm{X}$ & $\mathrm{X}$ \\
\hline Thalotia sp. & Periwinkle & rocky shores & $\mathrm{X}$ & $\mathrm{x}$ & $\mathrm{x}$ \\
\hline $\begin{array}{l}\text { Trapezium } \\
\text { bicarnatum }\end{array}$ & & $\begin{array}{l}\text { crevices in coral } \\
\text { boulders }\end{array}$ & & $\mathrm{X}$ & \\
\hline $\begin{array}{l}\text { Trapezium } \\
\text { sublaevigatum }\end{array}$ & & $\begin{array}{l}\text { oyster clumps/littoral } \\
\text { shell debris }\end{array}$ & $\mathrm{X}$ & $\mathrm{X}$ & \\
\hline Trichomya hirsuta & Hairy mussel & tidal estuary & $\mathrm{X}$ & $\mathrm{X}$ & $\mathrm{X}$ \\
\hline Trisodos tortuosa & & littoral sand & $\mathrm{X}$ & $\mathrm{X}$ & \\
\hline Turritella terebra & Waxen screw shell & sandy mud & $\mathrm{X}$ & & \\
\hline Velacumantis australis & Australian mud whelk & estuary/mangroves & $\mathrm{x}$ & $\mathrm{X}$ & \\
\hline $\begin{array}{l}\text { Vepricardium } \\
\text { multispinosum }\end{array}$ & & littoral sand & $\mathrm{X}$ & & \\
\hline $\begin{array}{l}\text { Xanthomelon } \\
\text { pachastyla }\end{array}$ & Land snail & land & & $\mathrm{X}$ & $x$ \\
\hline
\end{tabular}

a Species identified in The Granites include XUs 1-3 and XU11. XUs 4-10 and 12-13 are not included so as to allow a comparison between the number of species identified in midden and chenier and in mixed deposits. 
Appendix B. Mort Creek Site Complex, A7, Excavation Data and Dominant Materials.

\begin{tabular}{|c|c|c|c|c|c|c|c|c|}
\hline$X U$ & $\begin{array}{c}\text { Mean XU } \\
\text { Depth }(\mathrm{cm})\end{array}$ & $\begin{array}{c}\text { Oyster }^{a} \\
\text { (g) }\end{array}$ & $\begin{array}{l}\text { Mud Ark } \\
\text { (g) }\end{array}$ & $\underset{(\mathrm{g})}{\text { Mussel }^{\mathrm{c}}}$ & $\begin{array}{c}\text { Other } \\
\text { Shell }^{\text {d }}(\mathrm{g})\end{array}$ & $\begin{array}{c}\text { Charcoal } \\
\text { (g) }\end{array}$ & $\begin{array}{c}\text { Bone } \\
\text { (g) }\end{array}$ & $\begin{array}{c}\text { Artefactual } \\
\text { Stone (g) }\end{array}$ \\
\hline 1 & NA & NA & NA & NA & NA & NA & NA & NA \\
\hline 2 & NA & NA & NA & NA & NA & NA & NA & NA \\
\hline 3 & 18.04 & 45.2 & 190.8 & 0.6 & 181.9 & 0.1 & $<0.1$ & 0 \\
\hline 4 & 20.24 & 128.8 & 828.2 & 5.6 & 165.4 & $<0.1$ & 0.2 & 0 \\
\hline 5 & 22.64 & 137.9 & 1482.8 & 7.9 & 304.9 & $<0.1$ & 0 & 0 \\
\hline 6 & 26.74 & 232.5 & 1434.2 & 17.4 & 360.2 & 0.1 & 0 & 0 \\
\hline 7 & 30.54 & 182.4 & 1322.1 & 13.0 & 312.6 & $<0.1$ & 0 & 0 \\
\hline 8 & 32.44 & 92.3 & 837.3 & 3.9 & 251.4 & $<0.1$ & 0 & 0 \\
\hline 9 & 37.04 & 148.5 & 262.7 & 7.9 & 270.2 & 0 & 0 & 0 \\
\hline 10 & 46.74 & 43.2 & 299.3 & 6.2 & 137.1 & 0 & 0 & 0 \\
\hline 11 & 57.94 & 83.4 & 438.2 & 8.7 & 148.2 & 0 & 0 & 0 \\
\hline 12 & 66.64 & 132.4 & 1112.4 & 4.6 & 266.2 & 0 & 0 & 0 \\
\hline 13 & 77.34 & 95.8 & 337.6 & 4.4 & 211.5 & $<0.1$ & 0 & 0 \\
\hline 14 & 89.14 & 203.7 & 571.3 & 10.3 & 256.6 & 0.1 & 0 & 0 \\
\hline
\end{tabular}

a Saccostrea commercialis

b Anadara trapezia

c Trichomya hirsuta

see Appendix A

NA Not available

Appendix C. Mort Creek Site Complex, White Patch, Excavation Data and Dominant Materials.

\begin{tabular}{|c|c|c|c|c|c|c|c|c|}
\hline XU & $\begin{array}{c}\text { Mean XU } \\
\text { Depth }(\mathbf{c m})\end{array}$ & $\begin{array}{c}\text { Oyster }^{\mathrm{a}} \\
(\mathbf{g})\end{array}$ & $\begin{array}{c}\text { Mud Ark }^{\mathrm{n}} \\
(\mathrm{g})\end{array}$ & $\begin{array}{c}\text { Mussel }^{\mathrm{c}} \\
(\mathrm{g})\end{array}$ & $\begin{array}{c}\text { Other } \\
\text { Shell }^{\mathrm{d}}(\mathrm{g})\end{array}$ & $\begin{array}{c}\text { Charcoal } \\
(\mathbf{g})\end{array}$ & $\begin{array}{c}\text { Bone } \\
(\mathbf{g})\end{array}$ & $\begin{array}{c}\text { Artefactual } \\
\text { Stone }(\mathbf{g})\end{array}$ \\
\hline 1 & 1.16 & 531.1 & 156.4 & 0.2 & 455.7 & 0 & 0 & 0 \\
\hline 5 & 21.82 & 938.2 & 315.7 & 19.3 & 1917.3 & 0 & 0 & 0 \\
\hline 8 & 34.92 & 1682.3 & 620.9 & 0.9 & 1956.7 & 0 & 0 & 0 \\
\hline
\end{tabular}

Saccostrea commercialis

b Anadara trapezia, Anadara granosa and Anadara rotundiscostata

c Trichomya hirsuta

d see Appendix A 
Appendix D. Mort Creek Site Complex, The Granites, Excavation Data and Dominant Materials.

\begin{tabular}{|c|c|c|c|c|c|c|c|c|}
\hline XU & $\begin{array}{c}\text { Mean XU } \\
\text { Depth (cm) }\end{array}$ & $\begin{array}{c}\text { Oyster } \\
(\mathbf{g})\end{array}$ & $\begin{array}{c}\text { Mud Ark } \\
(\mathbf{g})\end{array}$ & $\begin{array}{c}\text { Mussel }^{\mathbf{c}} \\
(\mathbf{g})\end{array}$ & $\begin{array}{c}\text { Other } \\
\text { Shell }^{\mathbf{d}}(\mathbf{g})\end{array}$ & $\begin{array}{c}\text { Charcoal } \\
(\mathbf{g})\end{array}$ & $\begin{array}{c}\text { Bone } \\
(\mathbf{g})\end{array}$ & $\begin{array}{c}\text { Artefactual } \\
\text { Stone (g) }\end{array}$ \\
\hline 1 & 3.0 & 35.3 & 1293.6 & 0.2 & 62.6 & 1.2 & 3.7 & 0 \\
\hline 2 & 8.4 & 89.7 & 1214.5 & 0.6 & 37.6 & 2.0 & 14.2 & 0.1 \\
\hline 3 & 14.2 & 81.0 & 1941.5 & 0 & 35.3 & 4.0 & 5.8 & 0.1 \\
\hline 4 & 18.5 & 34.2 & 114.2 & 0 & 15.0 & 0.8 & 0.5 & 0 \\
\hline 5 & 22.9 & 49.2 & 90.1 & 0 & 0.5 & 0.8 & 0.7 & 0 \\
\hline 6 & 28.3 & 0 & 53.2 & 0 & 0 & 0.2 & 0.2 & 0 \\
\hline 7 & 32.8 & 0 & 0.4 & 0 & 0.1 & 0 & 0.3 & 0 \\
\hline 8 & 37.6 & 0 & 2.5 & 0 & 0 & 0 & 0 & 0 \\
\hline 9 & 46.5 & 1.4 & 7.4 & 0 & 0 & 0.1 & 0.2 & 0 \\
\hline 10 & NA & 1.5 & 0 & 0 & 0 & 0 & 0 & 0 \\
\hline 11 & 52.1 & 395.1 & 812.0 & 4.1 & 52.7 & 0.9 & 3.7 & 0.7 \\
\hline 12 & 55.9 & 1398.2 & 950.1 & 24.4 & 800.9 & 0 & 0.9 & 0.6 \\
\hline 13 & 70.2 & 1326.3 & 641.5 & 38.2 & 999.4 & 0 & 3.5 & 0 \\
\hline
\end{tabular}

\footnotetext{
a Saccostrea commercialis

- Anadara trapezia and Anadara rotundiscostata

c Trichomya hirsuta

d see Appendix A

NA Not Available
} 